\title{
Composite Flours-Characteristics of Wheat/Hemp and Wheat/Teff Models
}

\section{Marie Hrušková, Ivan Švec, Ivana Jurinová}

Department of Carbohydrates and Cereals, Institute of Chemical Technology, Prague, Czech Republic.

Email: Marie.Hruskova@vscht.cz

Received August $14^{\text {th }}, 2012$; revised September 20 $0^{\text {th }}, 2012$; accepted September $27^{\text {th }}, 2012$

\begin{abstract}
Wheat/hemp and wheat/teff model composites were prepared as 90:10 and 80:20 w/w blends, using two different Czech commercial wheat flour samples (standards M, M1) and bright/dark forms of these non-traditional crops flour. The objective of this study was to determine the effect of alternative flour samples on the blend compositional profiles including dietary fibre content, on the technological quality described by modern Solvent Retention Capacity method and on laboratory baking test results. According to seeds composition, nutritional flour enrichment reached higher levels of protein (from approx. $13.0 \%$ about $30 \%$ vs. $6 \%$ ) and fibre contents (from approx. $3.3 \%$ about $50 \%$ vs. $30 \%$ ) in the case of hemp and teff samples. In terms of the SRC profile, the qualitatively better sample M was weakened by hemp flour additions, while somewhat worse sample M1 was improved by teff flour additions. Results from the baking test showed that the hemp composites were partly dependent on hemp flour form. Volumes of bread with bright hemp were diminished from $257 \mathrm{~mL} / 100 \mathrm{~g}$ up to $196 \mathrm{~mL} / 100 \mathrm{~g}$, the products containing dark hemp increased up to $328 \mathrm{~mL} / 100 \mathrm{~g}$. Teff-fortified bun volumes were evaluated in close range of $325-369 \mathrm{~mL} / 100 \mathrm{~g}$ against $381 \mathrm{~mL} / 100 \mathrm{~g}$ for standard M1. Sensorial score of wheat/hemp breads were worse owing to spicy taste and fatty aftertaste, while hay-like by-taste in wheat/teff bread could be tolerable of $10 \%$ in recipe.
\end{abstract}

Keywords: Wheat and Hemp Composite Flour; Protein Content; SRC; Dietary Fibre; Baking Test

\section{Introduction}

Bakery cereal products represent a basic daily-eaten food, and their role lay in a satiating function. Traditionally, mainly wheat and rye flours undergo fermentation and common rolls and bread are manufactured. Composite flours containing wheat and others cereals and non grain seeds have become popular in the baking technology due to customers' increasing interest in healthier food. In the last few decades, soy or spelt have been successfully included among common bakery raw materials. Furthermore, new non-traditional ingredients (e.g. amaranth, quinoa, lupine, chickpea, chia, hemp, teff) are receiving intense interest due to their multiple roles in enhancing the rheological properties of dough, overall bread quality and nutritional value [1-5].

Hemp (Cannabis sativa) is planted as two subspecies, namely ssp. culta a ssp. indica. The latter is called hash hemp and belongs to forbidden raw material with respect to intoxicating substances production [6]. Hemp flour composition differs according to used feedstock (dependent on variety and planting locality), means of preparation and defatting. However, protein, fat and starch rates are typically present at 30\% - 33\%, $7 \%$ -
$13 \%$ and approx. $40 \%$, respectively. Approx. two-thirds of hemp proteins is composed by edestin, belonging to low molecular weight globulins. Hemp flour is naturally gluten-free, suitable for celiatics. Hemp also contains a significant level of beta-carotene and vitamins $\mathrm{B}_{1}$ and $\mathrm{E}$. From a mineral contain perspective, benefit could be found in higher portion of iron and zinc [7].

Teff (Eragrostis tef) is classified into the cereal group of Poaceae (Gramineae) family. As was reported in [8], the main producer of teff is Ethiopia with annual production of 1 million tons ( $20 \%$ of local cereals yield). Flat bread injera (ingera) dominates the culinary treatments, and is manufactured from thin fermented dough with a portion of wheat flour. Because of its tiny seeds, the wholemeal flour is characterized by high rate of coating layers and sprout, resulting into higher content of insoluble polysaccharides. Teff proteins have non-gluten nature and owing to prevailing portion of prolamins belong to easily digestible ones. From a nutritional benefit viewpoint, high minerals content is cited (mainly iron, calcium, phosphorus and copper) and $\mathrm{B}_{1}$ vitamin [9].

Nowadays, testing of non-traditional plant materials is one of leading scopes in cereal chemistry, both for contemporary offer of baking product extending and for their 
nutritional value increasing. The work presented herein was aimed at exploration of wheat/hemp and wheat/teff flour effect on blends composition including dietary fibre content, on technological quality as Solvent Retention Capacity profile and on baking and consumer's quality of laboratory prepared bread.

\section{Materials and Methods}

For cereal mixture formatting, wheat flour samples $\mathrm{M}$ and M1 originated from harvest 2010 were used as base, and they were blended with two pairs of commercial samples of hemp (K1, K2) and teff (R1 or R2, respectively). Flour samples K2 and R2 differ from fine K1 and $\mathrm{R} 1$ ones by their dark colour and composition because of their wholemeal character (a diverse flour form). Model samples were blended in ratios 90:10 or 80:20 (w/w), and samples were named by type and content, e.g. K1.10 or R2.20.

Analysis of the basic analytical composition of wheat flour and tested composites included moisture (MOI), protein amount (PRO) and quality (Zeleny's sedimentation value, ZET) as amylase activity estimation (Falling Number, FN). For this aim, the Czech standards (ČSN 56 0512, ČSN ISO 1871 "Kjeldahl's method", ČSN ISO 5529 and ČSN ISO 3093) were followed. The solvent retention capacity (SRC) profiles were determined according to AACC Norm No. 56-11, including a standard $5 \mathrm{~g}$ flour sample and centrifugation by usage the Eppendorf 5702 apparatus (Eppendorf AG, Germany). The water, sucrose, sodium carbonate and lactic acid SRC values measured were abbreviated to WASRC, SUSRC, SCSRC and LASRC, respectively. Hemp and teff supplemented samples were assessed by insoluble, soluble and total dietary fibre contents determination (IDF, SDF and TDF, respectively) by using commercial Megazyme kit (AOAC method 985 29). Baking test was performed according to internal method of ICT Prague [10], examining wheat and composite flour water absorption and a final product characteristics (specific bread volume "SBV", bread shape "BRS" as height-to-diameter ratio, sensorial profile "SEN" and crumb firmness as a penetration rate "PEN"). Sensorial quality was described by 9-point score, including attributes from overall appearance to crumb chewiness and flavour, with limits of 9 and 27 point for the best and unacceptable bread consumer's quality, respectively. For the latter test, the penetrometer PNR 10 (Petrotest, Germany) was employed. Determined repeatability as variation coefficients for the SVB and PEN are 7.1\% and 9.8\% [11].

For statistical analysis, Statistica 7.1 software (Statsoft Inc., USA) was employed. ANOVA of flour type and addition factors was performed for hemp and teff flour model composites separately owing to both difference in wheat flour M and M1 quality (of group standards, re- spectively) and with respect to reversal influence of the tested non-traditional crops. Combining all gained data, a linear correlation matrix was calculated. The mentioned methods were evaluated on likelihood level 95\% ( $<<$ $0.05)$.

\section{Results and Discussion}

\subsection{Hemp and Teff Effect on Analytical Composition}

Pure wheat samples $\mathrm{M}$ and $\mathrm{M} 1$ were characterised by good baking quality (PRO 12.4\% and 13.2\%; ZET 41 $\mathrm{mL}$ and $41 \mathrm{~mL}$, respectively; Figure 1), suitable for partial replacement by non-gluten material. Furthermore, a difference between their amylase activity estimations (FN $336 \mathrm{~s}$ and $284 \mathrm{~s}$, respectively; Tables 1(a) and (b)) was insignificant with respect to measurement accuracy.

Both hemp and teff flour lowered flour moisture content depending on the additive used (Tables 1(a) and (b)), with a maximal decrease of $0.8 \%$. Comparing hemp and teff mixtures, MOI levels were subordinated to value determined for basic flour M or M1, and in both groups impacts of alternative flour type or addition were statistically improvable. Protein properties changed in content and quality reversely, with higher impact of alternative flour type then addition level. Figure 1 documents a softer increase of PRO in case of teff addition (about 1.1 units for R2 composites) compared to approx. four-time higher change observed for K1.20 composite. Opposite to that, teff flour protein was not as dispersed in the wheat gluten structures as ZET values decreased to 30

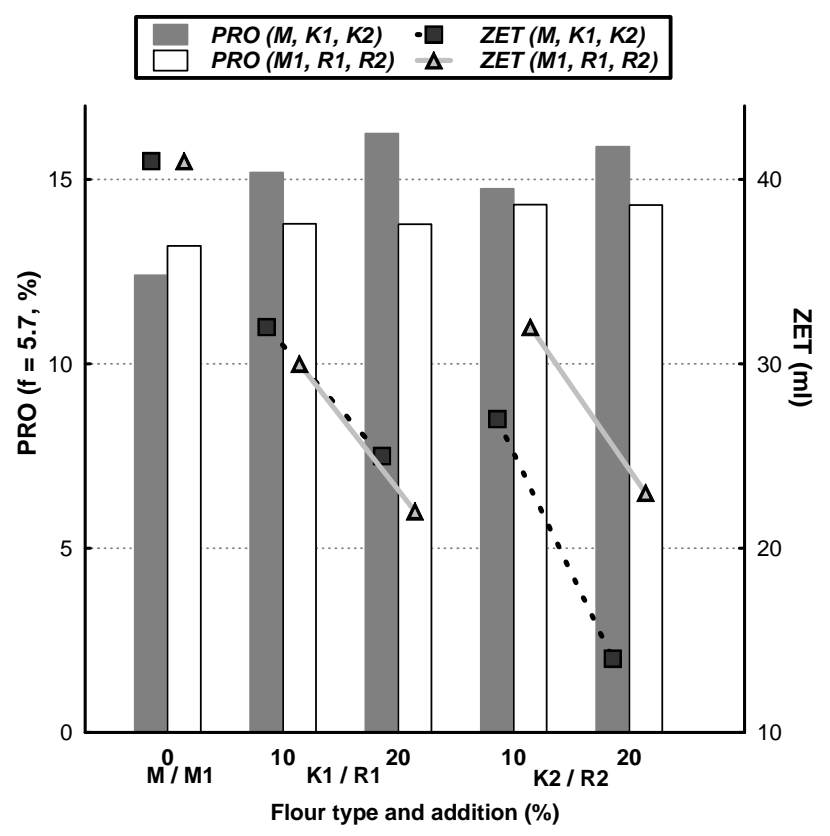

Figure 1. Hemp and teff influence on protein content (PRO) and quality as Zeleny value (ZET). M, M1 - wheat flour (standards); K1, K2 - hemp flour; R1, R2 - teff flour. 
vs. $32 \mathrm{~mL}$ and to $22 \mathrm{vs} .23 \mathrm{~mL}$ for blends with $10 \%$ and $20 \%$ of R1 and R2, respectively. For corresponding hemp composites, calculated descents were 9 vs. $16 \mathrm{~mL}$ and 14 vs. $27 \mathrm{~mL}$, respectively, i.e. observed change was governed by tested hemp flour type. All the results correspond to plant's botanical classification, e.g. teff be-

Table 1. Influence of non-traditional flour and addition on analytical features of wheat flour.

(a) Wheat/hemp composites

\begin{tabular}{|c|c|c|c|c|c|}
\hline \multirow{2}{*}{$\begin{array}{l}\text { Flour } \\
\text { type }\end{array}$} & \multirow{2}{*}{$\begin{array}{c}\text { Addition } \\
(\%)\end{array}$} & \multicolumn{2}{|r|}{ MOI (\%) } & \multicolumn{2}{|r|}{$F N(\%)$} \\
\hline & & Value & Means variation & Value & Means variation \\
\hline$M$ & 0 & 11.6 & $\mathrm{a} ; \mathrm{A}$ & 336 & $\mathrm{a} ; \mathrm{A}$ \\
\hline \multirow[t]{2}{*}{$K 1$} & 10 & 11.2 & \multirow[b]{2}{*}{$\mathrm{a} ; \mathrm{A}$} & 307 & \multirow[b]{2}{*}{$\mathrm{a} ; \mathrm{A}$} \\
\hline & 20 & 10.8 & & 297 & \\
\hline \multirow[t]{2}{*}{$K 2$} & 10 & 11.3 & \multirow{2}{*}{$\mathrm{a} ; \mathrm{A}$} & 306 & \multirow{2}{*}{$\mathrm{a} ; \mathrm{A}$} \\
\hline & 20 & 11.0 & & 286 & \\
\hline
\end{tabular}

(b) Wheat/teff composites

\begin{tabular}{lccccc}
\hline$M 1$ & 0 & 12.6 & a; A & 284 & a; A \\
$R 1$ & 10 & 12.2 & & 305 & \\
& 20 & 12.0 & a; A & 319 & a; A \\
$R 2$ & 10 & 12.3 & & 305 & \\
& 20 & 12.1 & a; A & 293 & a; A \\
\hline
\end{tabular}

a. a: column means of $\mathrm{M}, \mathrm{K} 1$ and $\mathrm{K} 2$ (or M1, R1 and R2) signed by the same letter are not statistically different $(\mathrm{p}<0.05)$. b. A: column means of additions 0,10 and $20 \%$ signed by the same letter are not statistically different $(\mathrm{p}<$ $0.05)$. longs in the same family as wheat, thus partially similar protein fractions categorisation in flour from both species was indirectly confirmed. On the other hand, neither hemp nor teff flour was affected enzymatic activity as the slightly decreasing and increasing FN values, respectively, were not statistically different and practically verifiable (Tables 1(a) and (b)).

Analytical data of wheat flour and its composites with 10 and $20 \%$ of teff flour was published recently [12]. For wheat flour as control, contents of crude protein and DF were $10.5 \%$ and $4.1 \%$, respectively. Both teff additions increased both parameters (to $10.6 \%$ and $10.9 \%$ for crude protein and to $4.2 \%$ and $4.3 \%$ for DF, respectively), but those changes were statistically insignificant.

\subsection{Hemp and Teff Effect on SRC Profiles}

The overall holding capacity of all network-forming flour constituents, level of damaged starch, pentosans and gliadins characteristic as well as glutenin characteristics were accounted for via SRC test $[13,14]$. Table 2(a) presents the results of the SRC test for M and hemp composites. In this regard, the quality of used wheat standards differed mainly in SCSRC and LASRC, i.e. in starch and glutenin physical stages, respectively. All four SRC's were affected by the hemp type at a higher rate than by wheat flour replacement level. The water, sucrose or sodium carbonate retention profile of the standard $\mathrm{M}$ was not seriously affected by the hemp flour $\mathrm{K} 1$ polysaccharides composition (a decrease between 4\% $17 \%$ ). Considering lower molecular weight fraction prevailing in hemp proteins, the LASRC descent from 182.5

Table 2. Influence of non-traditional flour and addition on solvent retention capacity profile of wheat flour.

(a) Wheat/hemp composites

\begin{tabular}{|c|c|c|c|c|c|c|c|c|c|}
\hline \multirow{2}{*}{ Flour type } & \multirow{2}{*}{ Addition (\%) } & \multicolumn{2}{|c|}{ WASRC (\%) } & \multicolumn{2}{|c|}{ SUSRC (\%) } & \multicolumn{2}{|c|}{ SCSRC (\%) } & \multicolumn{2}{|c|}{ LASRC (\%) } \\
\hline & & Value & Means variation & Value & Means variation & Value & Means variation & Value & Means variation \\
\hline$M$ & 0 & 90.9 & $\mathrm{~b} ; \mathrm{A}$ & 112.1 & $\mathrm{a} ; \mathrm{A}$ & 117.7 & $\mathrm{~b} ; \mathrm{A}$ & 182.5 & c; B \\
\hline \multirow[t]{2}{*}{ K1 } & 10 & 87.7 & \multirow{2}{*}{$\mathrm{b} ; \mathrm{A}$} & 93.1 & \multirow{2}{*}{ a; A } & 107.8 & \multirow{2}{*}{$\mathrm{b} ; \mathrm{A}$} & 128.8 & \multirow{2}{*}{$\mathrm{b} ; \mathrm{A}$} \\
\hline & 20 & 86.5 & & 102.3 & & 106.7 & & 112.1 & \\
\hline \multirow[t]{2}{*}{$K 2$} & 10 & 67.5 & \multirow[b]{2}{*}{$\mathrm{a} ; \mathrm{A}$} & 90.2 & \multirow[b]{2}{*}{$\mathrm{a} ; \mathrm{A}$} & 79.4 & \multirow[b]{2}{*}{$\mathrm{a} ; \mathrm{A}$} & 90.8 & \multirow[b]{2}{*}{ a; A } \\
\hline & 20 & 68.3 & & 74.3 & & 76.1 & & 77.2 & \\
\hline
\end{tabular}

(b) Wheat/teff composites

\begin{tabular}{|c|c|c|c|c|c|c|c|c|c|}
\hline$M 1$ & 0 & 84.8 & $\mathrm{a} ; \mathrm{A}$ & 103.3 & $\mathrm{a} ; \mathrm{A}$ & 89.1 & $\mathrm{a} ; \mathrm{A}$ & 97.6 & $\mathrm{a} ; \mathrm{A}$ \\
\hline \multirow[t]{2}{*}{$R 1$} & 10 & 83.6 & \multirow{2}{*}{$\mathrm{a} ; \mathrm{A}$} & 106.7 & \multirow{2}{*}{$\mathrm{a} ; \mathrm{A}$} & 96.3 & \multirow{2}{*}{$\mathrm{a} ; \mathrm{A}$} & 126.7 & \multirow{2}{*}{$\mathrm{a} ; \mathrm{A}$} \\
\hline & 20 & 83.1 & & 101.3 & & 91.5 & & 115.6 & \\
\hline \multirow[t]{2}{*}{$R 2$} & 10 & 84.6 & \multirow[b]{2}{*}{$\mathrm{a} ; \mathrm{A}$} & 99.7 & \multirow[b]{2}{*}{$\mathrm{a} ; \mathrm{A}$} & 93.6 & \multirow[b]{2}{*}{ a; A } & 151.6 & \multirow[b]{2}{*}{$\mathrm{a} ; \mathrm{A}$} \\
\hline & 20 & 83.5 & & 96.1 & & 94.5 & & 120.9 & \\
\hline
\end{tabular}

a. a - c: column means of M, K1 and K2 (or M1, R1 and R2) signed by the same letter are not statistically different (p < 0.05). b. A - B: column means of additions $0,10 \%$ and $20 \%$ signed by the same letter are not statistically different $(\mathrm{p}<0.05)$. 
units to 128.8 and 112.1 units (about $30 \%$ and $40 \%$ ) at $\mathrm{K} 1.10$ and K1.20 testing is understandable. Coating particles present in model $\mathrm{K} 2$ blends (wholemeal hemp flour form) are constituted of cellulose and hemi-celluloses, whose influence was identified through complete SRC profile of fortified M. Determined values of WASRC and SCSRC fell verifiably to $75 \%$ and $66 \%$ of the standard values, respectively. In wholemeal $\mathrm{K} 2$ composites, total pentosan and gliadin rates were lower compared to the K1 samples. The SUSRC values of composites with 10 and $20 \%$ of K2 hemp flour were lower and differed in a higher rate $(90.2 \%$ and $74.3 \%$, respectively. Finally, the LASRC course of $\mathrm{K} 2$ mixtures was similar to $\mathrm{K} 1$ ones, and gluten dilution reached a higher extent. Absorption of lactic acid solution dropped to 90.8 and 77.2 units for $\mathrm{K} 2.10$ and $\mathrm{K} 2.20$, respectively, representing 50 and $40 \%$ of value determined for $M$.

During testing of the two teff flour variants, when solvent retention was kept at levels comparable to wheat flour M1, even a little increase of the SCSRC was found (from 3 to 8 units; Table 2(b)). Between model composites containing $10 \%$ and $20 \%$ of teff flour, a difference circa 15 units of the SUSRC was calculated for both bright R1 and dark R2 types. The small negative change is therefore a result of teff flour type and addition level interaction. Composites behaviour in presence of lactic acid was unexpectedly different compared to diminishing of ZET values ad both substitution rates. By $10 \%$ of teff flour, LASRC's increased about $30 \%$ and $55 \%$ (to 126.7 and 151.6 units for R1 and R2 blends, respectively, against 97.6 units for M1), and consecutively fell to 115.6 and 120.9 units (for R1.20 and R2.20 samples; Table 2(b)). Summarised, teff flour type affected the SRC profiles somewhat stronger than addition level, but both factors were not identified as statistically significant.

\subsection{Hemp and Teff Effect on Dietary Fibre (DF) Content}

According to current research, hemp and teff seed (and similarly wholemeal flour) was characterised by crude fibre content of approx. 25\% - 30\% [15] and 3\% - 7\% [16]. In a dehulled stage and consecutively milled flour, fibre content was partially lowered, but the difference between the tested flour types was maintained. Ranges of DF content were $2.08 \%-3.44 \%, 1.02 \%-1.86 \%$ and $3.21 \%-5.25 \%$ for its insoluble, soluble and total constituents, respectively. The lowest contents were assessed in $\mathrm{M}$ and M1 standard, i.e. addition of hemp or teff flour unequivocally meant nutritional improvement of that basic bakery raw material.

Figure 2 shows that wheat flour enhancing effect was about $33 \%$ higher for hemp composites compared to teff ones (e.g. $3.44 \%$ and $2.60 \%$ of IDF for $80 / 20$ composites,

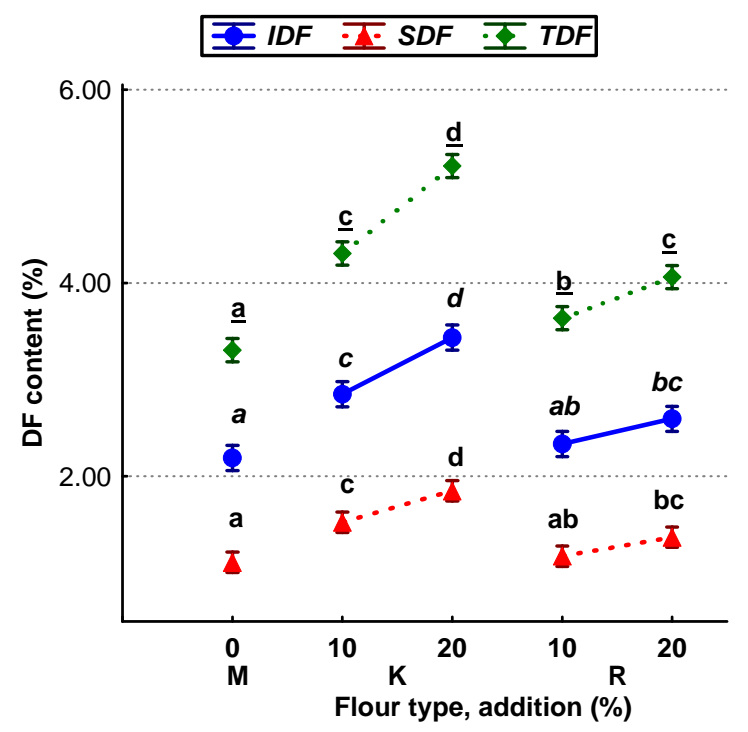

Figure 2. Hemp and teff flour influence on dietary fibre content. IDF, SDF, TDF-insoluble, soluble and total dietary fibre, respectively. $M, K, R$ : wheat, hemp and teff flour, respectively. a-d: values in single IDF, SDF and TDF lines signed by the same letter are not statically different $(p<$ 0.05).

respectively). Furthermore, a step accrual of $0.60 \%$ for the IDF was also twice higher in relation to the SDF, independently to tested bright or dark form of hemp flour. From courses of three DF constituents, prevailing impact of addition level could be noticed (Figure 2); there are composites K1/2.20 significantly differed from both wheat standard and from K1/2.10 ones.

In case of the teff blends, IDF, SDF and TDF contents increased to $0.60,0.40$ and $0.80 \%$ absolutely, respecttively. As shown in Figure 2, the ANOVA test shows a slower increase between additions of $10 \%$ and $20 \%$. Compared to the hemp composites, dominancy of the addition level factor over the tested teff form one was just partial; a strict discrimination of composite with $10 \%$ or $20 \%$ of teff was observed (variance "b" and "c", respectively) for the TDF only.

\subsection{Hemp and Teff Effect on Baking Test Results}

For both control bread samples prepared from $\mathrm{M}$ and $\mathrm{M} 1$ flour, the volumes of $257 \mathrm{~mL} / 10 \mathrm{~g}$ and $381 \mathrm{~mL} / 100 \mathrm{~g}$ represent common and very good baking quality, respectively. Changes in the SBV values adequately reflect bread recipe modification as increasing ratios of hemp or teff flour. Similarly for the PEN, representing general bread chewiness, approx. twice the penetration rate occurred for bread from M1 flour indicating that a very pleasant mouthfeel for consumer consumption.

Bakery products from composite flour K1.10 were characterised by satisfying and $\mathrm{K} 1.20$ by unacceptable 
SBV (diminishing about $7 \%$ and $24 \%$ ), thereby lower vaulting and very firm crumb (PEN lower than $5.0 \mathrm{~mm}$ ) (Table 3(a)) were measured. The higher hemp flour K1 content, the worse sensorial profile was determined. Crumb samples were progressively tougher during their chewing, taste was more spicy and aftertaste more fatty. However, wholemeal hemp four K2 improved prepared bread quality as SBV's rose about $14 \%$ and $28 \%$. Samples vaulting was comparable and PEN values were at least similar to the standard M bread parameters. Sensory characteristics of composite bread differed from pure wheat one again in flavour-fatty and sandy by-taste (coating particles in wholemeal flour type) at consummation.

For hand-made buns prepared from R1 or R2 model blends, evaluated bread quality changes were not as significant. Owing to better assessment of the standard M1 bread and also wheat-like character of teff flour, a partial descent in consumer's quality occurred at R1 or R2 usage. Sample volumes reached $97 \%$ vs. $88 \%$ and $85 \%$ vs. $91 \%$ of M1 bread in cases of R1.10 to R2.10 and R1.20 to R2.20 comparison, respectively. The main visual difference resulted in product's lower height, i.e. somewhat worse vaulting (BRS step-decrease about one tenth absolutely; Table 3(b)). Objectively measured crumb firmness pointed to tougher texture for bread according to both recipes containing $20 \%$ of teff flour as the PEN values were 9.9 and $15.1 \mathrm{~mm}$ for bright and dark form of flour, respectively, which differed considering test repeatability $(9.8 \%)$. Complex 9-point sensorial proof demonstrated a soft worsening of wheat/teff consumer's quality as the best and the unacceptable score could reached 9 and 27 points, respectively.

Changes in dough farinograph behaviour and baking test results for wheat/teff composites 100:0 (control), 90:10, 80:20 and 70:30 (w/w) were discussed in [12]. Compared to $\mathrm{M}$ or $\mathrm{M} 1$ values, the farinograph water absorption determined for British commercial wheat flour was higher (61.3\%). At teff flour additions of 10 and $20 \%$, that value increased softly but significantly to $62.2 \%$ and $62.8 \%$, respectively. The baking test results showed that the partial volumes were diminishing namely from $354 \mathrm{~mL} / 100 \mathrm{~g}$ for non-fortified bread to 346 and $322 \mathrm{~mL} / 100 \mathrm{~g}$, respectively. In bread sensorial score, authors pointed to sweet flavour light decrease and bitterness reversal increase (up to $89 \%$ and $195 \%$, respecttively); correspondingly, bread overall acceptability with 10 and $20 \%$ of teff in recipe dropped to $92 \%$ and $52 \%$ of control wheat bread. Furthermore, aftertaste increased up to twofold value.

\subsection{Correlation Analysis}

Covering all 10 tested sample data, a linear correlation matrix was calculated on using a $p<0.05$. To reduce a number of non-significant relationships, empty rows and columns were eliminated, and final Table 4 contains verifiable correlations only. Regardless to performed treatment, some reversal tendencies for hemp vs. teff composites described above limited a frequency of observed significant correlations (e.g. non-verifiable pair relationships between ZET and LASRC or FN and SCSRC against full correspondence among the SRC parameters themselves and to RWA). Between three basic

Table 3. Influence of non-traditional flour and addition on baking test results.

(a) Wheat/hemp composites

\begin{tabular}{|c|c|c|c|c|c|c|c|c|c|c|c|}
\hline \multirow{2}{*}{$\begin{array}{l}\text { Flour } \\
\text { type }\end{array}$} & \multirow{2}{*}{$\begin{array}{c}\text { Addition } \\
(\%)\end{array}$} & \multicolumn{2}{|c|}{$R W A$} & \multicolumn{2}{|c|}{$S B V$} & \multicolumn{2}{|c|}{$B R S$} & \multicolumn{2}{|c|}{ SEN } & \multicolumn{2}{|c|}{ PEN } \\
\hline & & Value & $\begin{array}{c}\text { Means } \\
\text { variation }\end{array}$ & Value & $\begin{array}{c}\text { Means } \\
\text { variation }\end{array}$ & Value & $\begin{array}{c}\text { Means } \\
\text { variation }\end{array}$ & Value & $\begin{array}{c}\text { Means } \\
\text { variation }\end{array}$ & Value & $\begin{array}{c}\text { Means } \\
\text { variation }\end{array}$ \\
\hline \multirow[t]{2}{*}{ K1 } & 10 & 55.6 & \multirow[b]{2}{*}{$\mathrm{a} ; \mathrm{A}$} & 239 & \multirow[b]{2}{*}{$\mathrm{a} ; \mathrm{A}$} & 0.47 & \multirow[b]{2}{*}{$\mathrm{a} ; \mathrm{A}$} & $14-15$ & \multirow[b]{2}{*}{$\mathrm{a} ; \mathrm{A}$} & 4.2 & \multirow[b]{2}{*}{$\mathrm{a} ; \mathrm{A}$} \\
\hline & 20 & 54.5 & & 196 & & 0.55 & & $16-17$ & & 1.6 & \\
\hline \multirow[t]{2}{*}{$\mathrm{K} 2$} & 10 & 52.8 & \multirow[b]{2}{*}{$\mathrm{a} ; \mathrm{A}$} & 293 & \multirow[b]{2}{*}{$\mathrm{a} ; \mathrm{A}$} & 0.56 & \multirow[b]{2}{*}{$\mathrm{a} ; \mathrm{A}$} & $12-14$ & \multirow[b]{2}{*}{$\mathrm{a} ; \mathrm{A}$} & 9.5 & \multirow[b]{2}{*}{$\mathrm{a} ; \mathrm{A}$} \\
\hline & 20 & 48.4 & & 328 & & 0.6 & & $13-14$ & & 12.7 & \\
\hline
\end{tabular}

(b) Wheat/teff composites

\begin{tabular}{|c|c|c|c|c|c|c|c|c|c|c|c|}
\hline M1 & 0 & 54 & $\mathrm{a} ; \mathrm{A}$ & 381 & $\mathrm{a} ; \mathrm{A}$ & 0.63 & $\mathrm{a} ; \mathrm{B}$ & 11 & $\mathrm{a} ; \mathrm{A}$ & 23.7 & $\mathrm{a} ; \mathrm{A}$ \\
\hline \multirow[t]{2}{*}{$\mathrm{R} 1$} & 10 & 55 & \multirow[b]{2}{*}{$\mathrm{a} ; \mathrm{A}$} & 369 & \multirow[b]{2}{*}{$\mathrm{a} ; \mathrm{A}$} & 0.53 & \multirow[b]{2}{*}{$\mathrm{a} ; \mathrm{AB}$} & 12 & \multirow[b]{2}{*}{$\mathrm{a} ; \mathrm{A}$} & 18.6 & \multirow[b]{2}{*}{$\mathrm{a} ; \mathrm{A}$} \\
\hline & 20 & 54.5 & & 325 & & 0.43 & & 14 & & 9.9 & \\
\hline \multirow[t]{2}{*}{$\mathrm{R} 2$} & 10 & 55.3 & \multirow[b]{2}{*}{$\mathrm{a} ; \mathrm{A}$} & 334 & \multirow[b]{2}{*}{$\mathrm{a} ; \mathrm{A}$} & 0.57 & \multirow[b]{2}{*}{$\mathrm{a} ; \mathrm{A}$} & 12 & \multirow[b]{2}{*}{$\mathrm{a} ; \mathrm{A}$} & 18.7 & \multirow[b]{2}{*}{$\mathrm{a} ; \mathrm{A}$} \\
\hline & 20 & 55.8 & & 345 & & 0.45 & & 13 & & 15.1 & \\
\hline
\end{tabular}

a. a: column means of M, K1 and K2 (or M1, R1 and R2) signed by the same letter are not statistically different (p < 0.05). b. A - B: column means of additions $0,10 \%$ and $20 \%$ signed by the same letter are not statistically different $(\mathrm{p}<0.05)$. 
Table 4. Significant correlations between analytical, nutritional and bread quality characteristics $(N=10 ; r=0.63, p<0.05)$.

\begin{tabular}{|c|c|c|c|c|c|c|c|c|c|c|}
\hline & $P E N$ & SEN & $R W A$ & $T D F$ & $S D F$ & $I D F$ & LASRC & SCSRC & SASRC & ZET \\
\hline$P R O$ & - & 0.85 & - & 0.92 & 0.89 & 0.91 & - & - & -0.68 & -0.7 \\
\hline ZET & - & - & 0.67 & -0.8 & -0.75 & -0.75 & - & - & 0.73 & - \\
\hline$F N$ & - & - & - & - & - & - & 0.76 & - & - & - \\
\hline WASRC & - & - & 0.85 & - & - & - & 0.75 & 0.88 & 0.8 & \\
\hline SUSRC & - & - & 0.85 & -0.69 & -0.67 & -0.67 & 0.71 & 0.7 & & \\
\hline SCSRC & - & - & 0.81 & - & - & - & 0.81 & & & \\
\hline LASRC & - & - & 0.83 & - & - & - & & & & \\
\hline$I D F$ & -0.69 & 0.81 & - & 0.99 & 1 & & & & & \\
\hline$S D F$ & -0.72 & 0.8 & - & 0.99 & & & & & & \\
\hline$T D F$ & -0.65 & 0.82 & - & & & & & & & \\
\hline$S B V$ & 0.92 & - & & & & & & & & \\
\hline SEN & -0.76 & & & & & & & & & \\
\hline
\end{tabular}

PRO — protein content, ZET — Zeleny sedimentation value, FN—Falling Number; WA-, SU-, SC-, LASRC—water, sucrose, sodium carbonate and lactic acid solvent retention capacity, respectively; IDF, SDF, TDF-insoluble, soluble and total dietary fibre content, respectively. RWA-recipe water added, SBVspecific bread volume, SEN—bread sensory profile, $\mathrm{PEN}$ - crumb penetration.

technological features (PRO, ZET, FN), interesting and unequivocal relations were found to all three DF constituents, confirming a positive nutritional effects of both non-traditional crop addition. Moreover, content of DF (i.e. polysaccharides) has positively contributed to bread sensorial acceptability, and vice versa to crumb firmness (PEN).

Finally, agreement in SBV and PEN or SEN data confirmed satisfying features exchangeability, mainly in the former pair $(r=0.92$; Table 4). A negative binding between SEN and PEN could be explained by reversal scoring, i.e. the higher both PEN and SEN at the same time, the better crumb texture and less acceptable overall consumer's quality, respectively.

\section{Conclusions}

Model cereal flour composites were blended from Czech commercial wheat flour and pairs of hemp and teff flour, which differed in their bright and dark (wholemeal) form. Chosen mixing ratios were 90:10 and 80:20 (w/w) identically for both non-traditional crops. The objective of this study was to determine the effect of alternative flour samples effect on the blends compositional profiles including dietary fibre content, on the technological quality described by modern Solvent Retention Capacity method and on the laboratory baking test result.

Regardless to tested flour form, hemp and teff additions have positively influenced protein and also dietary fibre contents in blends; however, enhancing rate differed between tested materials favourably for hemp flour. Determined increments of approx. $30 \%$ and $50 \%$, (versus $6 \%$ and $30 \%$ ) respectively, correspond with both crop botanical categorisation and could have a positive reflection in human's diet.

On the other hand, fermented product baking and consumer's quality was at least maintained at teff composites testing. Bread volumes were comparable to wheat control one, with crumb firmness and sensorial score kept on acceptable levels. Compared to fatty spicy aftertaste of wheat/hemp bread, hay-like one in teff bread flavour could be tolerable at $10 \%$ of teff in recipe. Known data correspondence was confirmed between protein content and quality vs. dietary fibre content. Dietary fibre also influenced bread volume, crumb texture and consumer's quality of manufactured bread.

\section{Acknowledgements}

The research was performed under project "New Food" of the NAZV, Czech Republic, No. 321511510.

\section{REFERENCES}

[1] D. Best, "Whole Seed-Better than Whole Grain?" Cereal Food World, Vol. 54, No. 5, 2009, pp. 226-228. doi:10.1094/CFW-54-5-0226.

[2] L. M. Ohr, "Good-for-You-Grains," Food Technology, Vol. 63, No. 1, 2009, pp. 57-58, 60-61.

[3] M. Hrušková, "Wheat,” In: J. Prugar, Ed., Plant Products Quality on Beginning of the Third Millennium, VÚPS, Brno, 2008, pp. 75-103.

[4] M. Miranda, D. Bazile, F. Fuentes, A. Vega-Gálvez, I. Quispe, R. Lemus and E. A. Martínez, "Quinoa Crop Biodiversity in Chile: An Ancient Plant Cultivated with Sustainable Agricultural Practices and Producing Grain of Outstanding and Diverse Nutritional Values," Proceed- 
ings of the 5th International Technical Symposium on Food Processing, Monitoring Technology in Bioprocesses and Food Quality Management, Nantes, 18-20 April 2011, p. 1180.

[5] S. Mironeasa, G. G. Codina and C. Mironeasa, "The Effects of Wheat Flour Substitution with Grape Seed Flour on the Rheological Parameters of the Dough Assessed by Mixolab," Journal of Texture Studies, Vol. 43, No. 1, pp. 40-48. doi:10.1111/j.1745-4603.2011.00315.x

[6] C. Perlín, "Hemp as a Food," Výživa a Potraviny, Vol. 57, No. 4, 2002, pp. 121-122.

[7] J. Peč and J. Dušek, "Composition and Utilization of Hemp Oil with Respect to Therapeutic Effect of Essential Fat Acids," Praktické Lékárenství, Vol. 4, No. 2, 2008, pp. 86-89.

[8] M. I. Gomez and S. C. Gupta, "Millets," In: L. Trugo and P. M. Finglas, Eds., Encyclopedia of Food Sciences and Nutrition, Elsevier, Amsterdam, 2003, pp. 3974-3979. doi:10.1016/B0-12-227055-X/00791-4

[9] P. Arguedas Gamboa, "Teff Survey on the Nutritional and Health Aspects of Teff (Eragrostis Tef)," 2008.

http://educon.javeriana.edu.co/lagrotech/images/patricia arguedas.pdf

[10] M. Hrušková, I. Švec and O. Jirsa, "Correlation between Milling and Baking Parameters of Wheat Varieties," Journal of Food Engineering, Vol. 77, No. 3, 2006, pp. 439-444. doi:10.1016/j.jfoodeng.2005.07.011

[11] T. Hofmanová, "Charakteristiky Směsí Vybraných Druhů
Tuzemských Obilovin," Master's Thesis, Institute of Chemical Technology, Prague, 2011.

[12] I. Alaunyte, V. Stojceska, A. Plunkett, P. Ainsworth and E. Derbyshire, "Improving the Quality of Nutrient-Rich Teff (Eragrostis tef) Breads by Combination of Enzymes in Straight Dough and Sourdough Breadmaking," Journal of Cereal Science, Vol. 55, No. 1, 2012, pp. 22-30. doi:10.1016/j.jcs.2011.09.005

[13] C. S. Gaines, "Report of the AACC Committee on Soft Wheat Flour. Method 56-11. Solvent Retention Capacity Profile," Cereal Foods World, Vol. 45, 2000, pp. 303306.

[14] M. Kweon, L. Slade and H. Levine, "Solvent Retention Capacity (SRC) Testing of Wheat Flour: Principles and Value inPredicting Flour Functionality in Different Wheat-Based Food Processes, as Well as in Wheat Breeding. A Review," Cereal Chemistry, Vol. 88, No. 6, 2011, pp. 537-552. doi:10.1094/CCHEM-07-11-0092

[15] EFSA Journal, "Scientific Opinion on the Safety of Hemp (Cannabis Genus) for Use as Animal Feed," EFSA Journal, Vol. 9, No. 3, 2011, pp. 1-41.

http://www.efsa.europa.eu/en/efsajournal/doc/2011.pdf.

[16] R. Phanacharoensawad, "The Potential for Growing Teff (Eragrostis Tef [Zucc.] Trotter) in Thailand," Asian Journal of Food and Agro-Industy, Vol. 2, 2009, pp. S125S131.

http://www.ajofai.info/Abstract/The $\% 20$ potential $\% 20$ for $\% 20$ growing $\% 20$ tef $\% 20 \% 28$ eragrostis $\% 20$ tef $\% 20 \% 28 \mathrm{zu}$ cc. $\% 29 \% 20$ trotter $\% 29 \% 20 \mathrm{in} \% 20$ thailand.pdf. 